ARTICLE

\title{
Stigma and fear during COVID-19: essentializing religion in an Indian context
}

\author{
Debajyoti Biswas (1D ${ }^{1 凶}$, Sanjukta Chatterjee (1D ${ }^{2} \&$ Parvin Sultana (1) ${ }^{3}$
}

A cursory inquest into the effects of SARS-CoV-2 exposes how easily the ramification of the pandemic has moved over from the physio-social to the psychosocial state of humans all over the world. Derogatory nomenclatures such as 'Chinese-virus' or 'Corona-jihad' can be seen as a part of a disjunctive politics of 'representation' as opposed to 'representing' with a metonymic effect. Such politics violates the protocol on naming new human infectious diseases set by World Health Organization. It also insinuates a long-term socio-political impression on the mental state of an individual or a social group, which may have an emasculating effect on the global solidarity to fight the virus. This calls for a nuanced psychosocial investigation with a specific analysis of how the ensuing stigmatization and fear can aggravate the contagion. With specific reference to the Indian sub-continent, this paper explains the socio-political orientation behind the essentialisation of a religious group that has led to the indictment of the minority community. By using Wagner's theory of essentialisation and Critical Race Theory, this article shall endeavor to explore how media may play a crucial role in stigmatizing communities. Secondly, the paper also argues that the spiraling effect of such ostracisation leads to stigma and fear within the group which is not only dehumanizing but also detrimental to the concerted effort to contain the pandemic.

\footnotetext{
${ }^{1}$ Bodoland University, Kokrajhar, India. ${ }^{2}$ Raiganj University, Raiganj, India. ${ }^{3}$ Pramathesh Barua College, Gauhati University, Guwahati, India.

凶email: deb61594@gmail.com
} 


\section{Introduction}

ocial groups often define and redefine themselves vis-a-vis other groups owing to changing political, economic, and cultural situations (Stangor, 2014). While doing so, groups attribute characters to themselves, as well as to other groups, and believe that these characters are defining (ibid). While this may be seen as a part of socialization, it becomes problematic when negative characters are portrayed as essential attributes of certain groups. The negative portrayal is then used to dehumanize the groups by putting them in an inferior position. Essentialisation however goes on simultaneously at multiple levels according to Wagner and Semati (Holtz et al., 2009; Semati, 2010). Right-wing politics have essentialized such characters of the majority community and differentiated them from others by essentializing certain characters of the 'other' community (Holtz and Wagner, 2008). This differentiation has been reflected in political discourse as well. It has been internalized by certain social groups and also by the larger Indian society to some extent. Social cleavage, be it in lines of religion, caste, or gender, is not new in India. It stays dormant under normal circumstances but becomes prominent at times of social conflicts. During social conflicts, individuals identify themselves with groups they have their affinity with. For example language, religion, caste, and even gender may become a basis of their affinity. Although associations based on identity remains dormant during peacetime, it may take a violent form during the conflict of interest situations. It was witnessed in India during the religious riots, Babri Masjid demolition, Nellie Massacre, Kashmiri Pandit's exodus, and so forth. This fragmentation came to the forefront again during the COVID-19 crisis. Whereas viral diseases are not community-centric, it has been witnessed that by using majoritarian rhetoric, people belonging to lower-income groups, castes, and minority religions are either treated unequally or are implicated as super-spreader of the virus. This prejudice can be understood through the lens of Critical Race Theory (CRT) which reads into the form of hierarchization that enables a hegemonic process to subjugate weaker citizens. Critical Race Theory (CRT) "holds that race and races are products of social thoughts and relations. Not objective, inherent or fixed, they correspond to no biological or genetic reality; rather races are categories that society invents, manipulates, or retires when convenient" (Delgado \& Stefancic, 2016). Although the phrase "race" is not concurrent in Indian discourse on religious discrimination ${ }^{1}$, yet we can deconstruct the inter-community relations through CRT. The COVID19 pandemic has exposed the social hierarchies once again, and it became more pronounced in the news aired by print and electronic media on one hand and the narrative generated by politicized groups on the other hand. The caste system (Varna), which was once encoded in the ancient Indian social system based on the vocation of the individual, has gradually become entrenched in the social life of present times. Although the Constitution of India safeguards an individual against all forms of discrimination theoretically, in everyday practice the discriminatory approaches betray its presence in the collective memory. Under such circumstances, the constitutional framework cannot help in changing the belief system that exists in one's mind. It will be interesting to see how that collective memory is revisited again and again through the essentialisation process in conjunction with the role played by the media houses in aggravating the same. India is a country where multiple races have mingled and multiple languages and religions have flourished. Therefore to have a majoritarian view in a democratic country is not only unsettling for the religious minorities but may also have long-term social ramifications.

The recent polarization in India has been supplemented by an assertive religiosity of Muslims, who comprise almost $14 \%$ of the population. Here religion became a defining marker of Muslims, who as a community is marked by internal and at times conflicting differences. The negligence of a small group of Muslims, who came together for a religious congregation at New Delhi's Markaz during the last week of February 2020 (Yamunan, 2020; Biswas and Sultana, 2020), was misconstrued into a conspiracy theory. They have been accused of 'Corona-jihad', and as such were reprimanded for spreading the highly contagious disease among the Indians. The ignorance and religious conservatism of Tablighi Jamaats, who is also staunchly criticized by other Muslims, was conflated with conspiracy. As a result, the entire community was accused of plotting against the nation. As media continued stressing that the Tablighis comprised $30 \%$ of the cases at that level, the entire focus was shifted on criminalizing potentially sick persons. Therefore this paper argues that a nexus of a section of media and some political groups communalized the spread of COVID-19. As a result, crucial aspects of the crisis like medical management, economic relief, and migrant labourers' need were not given enough emphasis. The paper also looks at how media emphasized so much on the religious identity of infected persons that it created an atmosphere of stigma and fear and discouraged many people from disclosing their travel history to Markaz thereby aggravating the contagion further. This diversion, miscommunication, and mistrust amongst stakeholders have worsened the COVID-19 situation. Whereas the need of the hour was to show solidarity amongst nations and communities, there was instead a distrust, politicization, and vilification of communities at a micro and macro level. At a micro level, the inter-community relation within the country was strained, and on a macro level, the relationship between nations was affected. This analytical paper can help in understanding how social groups are essentialized during pandemics by the media and competing groups through news items published in print/electronic media. As essentialisation leads to the rise in stigma and fear among communities, a nuanced approach in deciphering the causes can help us in handling the crisis efficiently in the future. For this purpose, the paper engages theoretical concepts on essentialisation propounded by Wagner and Semati, and Critical Race Theory to analyze social relations and conflicts during the COVID-19 pandemic in India. Although substantial works on how caste and religious politics operate in a majoritarian state have been addressed in works like On Nationalism by Romila Thapar, A.G. Noorani and Sadanand Menon, What the Nation Really Needs to Know: The JNU Nationalism Lectures edited by Rohit Azad, Janaki Nair, Mohinder Singh, and Mallarika Sinha Roy, Majoritarian State: How Hindu Nationalism is Changing India edited by Angana P. Chatterjee, Thomas Blom Hansen and Christopher Jaffrelot, The Doctor and the Saint by Arundhati Roy, Hindutva as Political Monotheism by Anustup Basu to name a few, yet how the society and media respond to religious politics during pandemics in Indian society has not been addressed systematically. It would help researchers in understanding the function and responsible role of media during pandemics in India. When freedom of the press is extolled in every civilized society, an attempt to use media as an essentializing tool may prove disastrous. This paper takes a look at how media and political groups have used essence during COVID-19 Pandemics. However, the paper is limited to addressing only the news in electronic/Print media. Future researchers may look up how a similar process has taken place in social media platforms like Facebook or Twitter. The paper is divided into five sections: Introduction, Essentialisation of Social Groups, Role of Media in Essentialising Religion, Stigma and Fear during Pandemic, and Conclusion.

\section{Essentialization of social groups}

Essentialism is a philosophical premise that entails the theory of 'universals'. Based on Plato's notion of 'ousia', 'essentia' or essence 
means 'to be' (Wagner et al., 2009). These universals are natural attributes and act as a mark of identicality in human beings who are said to possess them. The presence of certain (one or more) 'universals' in individuals essentially directs them towards a common belonging which precipitates in social group memberships. The idea of essences being 'inherent, innate and unchanging' (Sahin, 2018) renders them incapable of human intervention, and the group functions as an automated and naturalized entity. The natural-ness of the universals also implies the proposition that the social groups cannot compromise and/or negotiate any change to their inherent tendencies, actions, and functional premises. The group functions as a unit- an entity. This aura of being naturalized has been instrumental in resisting dialogs between the contesting social groups because there is a certain 'cultural tightness' (Jackson et al., 2019) in the social display of their ingroup behavior. In their outward behavior, the members of the social group tend to display certain characteristics that emanate from the presence of the common 'universals' in the group members. The closed social groups thereby construct their identity through the exhibition of these 'surface characteristics' (Wagner et al., 2009). This determines their representation in the wider social milieu and distinguishes them from the members of the outgroup who affiliate to other 'universals' and thereby can never be on the same plane of understanding as to the ingroup members. The groups come to be accepted as 'natural kinds' (Quine, 1969) and strive to maintain their 'entitativity' (Campbell, 1958). The entitativity of the group is based on either essence, agency, or unity of the group members (Kashima 2004; Agadullina and Lovakov, 2017). The politics of essentialization builds itself on the mode of representation and to the degree of accuracy in the execution of the same.

The conflict of interests between the ingroups and the outgroups is necessary for the existence of these groups and is unavoidable. The essentializing tactics of discursive representation read these exemplars of group behavior and appropriate them as an end to the desired means. The tools of essentialization are employed to construct a necessary 'Other' in the form of an essentialized social category (Wagner et al., 2009). This Other is either 'dehumanized' (Haslam, 2006) or subjected to 'politics of demonization' (Semati, 2011) to foster the emotions of hatred, anger, fear, and disgust by the essentializers. As the boundaries of the social categories are impermeable the real nature of the group can only be understood through the representational lens of the outgroups. A social organization or a religious outfit normally consists of multiple ingroups who also remain elusive about the real essence underlying each -except through the demonstrative social behavior of the co-ingroups. Any perceiver belonging to the outgroup can politically generalize the action of a particular ingroup as the 'metonymic representation' of the greater social/ religious/political category of which it is a part. This is exactly what has been happening to the representation of the Indian Muslim in the backdrop of COVID-19. An Islamic ingroup named 'Tablighi Jamaat' is being held responsible for spreading the pandemic to the remotest corners of India and consequentially the Indian Muslim has to reel under a fresh lease of Islamophobia. 'Tablighi Jamaat' has come to essentially nominalize for the entire Muslim population in India that has historically been a witness to this 'clash of civilisations' (Huntington, 1996). The activities of this essentially purist Islamic ingroup have become the sole signifier of Islam. The collective responsibility of the actions of the individual members of this religious ingroup has to be borne by the group and the perceiver will judge the group on its basis. (Denson et al., 2006). However, this ascription of metonymic identification to the group as the essential representative of the entire religious community is not a novel phenomenon. Islamophobia as a phenomenon has its genesis in the post-Cold war period when Europe and America constructed this essential Other in the image of the Muslim through the dual policies of reinstated social inclusion and ideological exclusion (Semati, 2010). The traces of neo-racist propaganda instilled this fear of the 'ghost' of Islam that has till then continued to 'haunt' the societies all over the world (Semati, 2010). The incidences such as $9 / 11$ in the context of the West and that of the attack on the Indian parliament on $13^{\text {th }}$ December 2001 (both supposedly attributed to extremist groups stating their affiliation to Islam) have been represented in popular culture and media to such an extent that a 'monstrosity' has been added to the entire religion and its followers. It has aided in the construction of a naturalized terrorizing image of the Muslim and aided in the politics of 'psychological essentialization' (Holtz and Wagnor, 2008). This effective formation of the Other is essentially racist and feeds on the politics of exclusion and segregation that '...inscribes itself in practices (forms of violence, contempt, intolerance, humiliation, and exploitation), in discourses and representations which are so many intellectual elaborations of the phantasm of prophylaxis or segregation (the need to purify the social body, to preserve 'one's own' or 'our' identity from all forms of mixing, interbreeding or invasion) and which are articulated around stigmata of otherness (name, skin color, religious practices' (Balibar and Wallerstein, 1988). This neo-racist reading of the Tablighi issue in India is an extrapolation of the irreconcilable differences between the two prominent religious groups-the Hindus and the Muslims. To establish the 'truth' that is supposed to be unearthed by the essentializers, they rely on the memory of the 'mnemonic clashes' (Kello, 2017) between the contesting groups and thereby justify their assumptions about the purposes of the group.

The functionality of the ingroups in defining the actions of the outgroup is normally in a derogatory vein. The ingroup is judgemental about the actions of the outgroup and this results in prejudice and racism. A 'nominalized category label' (Locke, 1689/1975; Wagner et al., 2009) aids in the essentialization of a social category and renders it unalterable. The group's appearance as a natural kind reinstates the boundaries of that group and the essentializers utilize this tightness to justify and 'legitimize' their relationships with these groups. Not only in the Euro-American social consciousness but also in India the belief system of the masses has so been conditioned that the Muslims are seen as a monolithic entity. Semati has contested this idea of Muslims as a closed category. While critiquing essentialization of Islam, he speaks of 'positive essentialism' and 'negative essentialism' about Islam (Semati, 2011). While positive essentialism tries to view the issues from the standpoint of Islam, negative essentialism tends to 'vilify religion'. He critiques the approach to Islam from a 'spurious' non-Islamic point of view and in this context critically analyses James Lull's Culture-on-Demand: Communication in a Crisis World (2007). Semati stresses the politics of essentialism in works such as these that are no in-depth studies of the Muslims in all the societies over the world but are fragmented representations of Islam as a Faith. Semati proposes that Islam as discourse is to be separated from Islam as a faith. He speaks against the 'clash of civilizations paradigm'. The Corona-Jihad issue in the recent context of Indian Muslims is but an extension of this kind of essentialist scholarship that Semati has discussed.

Religion is not a natural construct but a cultural construct. 'It denotes a historically transmitted pattern of meanings embodied in symbols, a system of inherited conceptions expressed in symbolic forms by means of which men communicate, perpetuate, and develop their knowledge about and attitudes toward life' (Geertz, 1993). To essentialize religion the essentializers tend to generalize the incidents and bring all incidents down to the same plane of public cognition and understanding. Hence all Muslims all over the world automatically become subscribers to the terror of certain extremist groups that proclaim themselves to 
be the 'real' Muslims. The names Al Qaeda or Hizbul Mujahideen have become synonymous with Muslims and the construction of the Muslims as a terrorizing religion is propagated among the outgroups. Prejudice dominates the propagation of the myth of identity and the role of media nurtures it according to the need of the hegemonic forces of power in action. Inferentially the 'Tablighi Jamaat' stands equated with terrorism and antinationalism and their congregation at New Delhi acquire the novel nominalization- Corona-jihad. An integral part of fiqh literature, the concept of Jihad in Islam is the need to struggle, work, do, exert, and other such verbs of action that provide the impetus to the follower of Islam to perform certain actions as a Muslim. The term has a wide range of meanings that range from perpetuating a 'holy war' to the propagation of education (Ramlan and Hakim, 2016). Contemporary explanations on the meaning of jihad have been overshadowed by the extent to which it has been essentialized. As the 'Tablighi Jamaat' is an Islamist ingroup, therefore, the transgression on their part, instead of being viewed as an act of disobedience is essentialized to represent bio-terrorism or Corona-Jihad. The metonymic identification of the action of the Jamaat in the co-relational backdrop of terrorist activities undertaken by Islamist ingroups all over the world stigmatized the entire Indian Muslim community.

The Pandora's Box of distrust once opened is hard to be contained. The essentialized representation of the role of the 'Tablighi Jamaat' led to a religion-cultural causal construct in the psychoscapes of citizens who were already disturbed by the lockdown and the incessant spread of the novel coronavirus (A transition from Physio-social to Psycho-social state). This constructed figure of the monolithic and reductionist 'Muslim Other' imagined endangering the lives of the countrymen could be fatal enough to unleash the undercurrent of hatred and apathy among the members of the society and could lead to a total breakdown of peaceful co-existence. As an essentializing tool, prejudice plays a significant role in the construction of social identity. In a research report submitted at the University of Kent, Dominic Abrams studied the impact of prejudice in the context of the interrelations of social groups. The definition of prejudice on which he bases his research is a 'bias which devalues people because of their perceived membership of a social group'. Abrams states that prejudice is 'mediated psychologically' and people interpret the social context as they understand the relationships of the various social groups. Prejudice against a social group also leads to a sense of perceived threat in the minds of the people. Abrams also studies the impact of stereotyping on the formation of prejudice and the ultimate discrimination that it precipitated. He states '...stereotypical expectations help to make life predictable, but the problem is that, inevitably, they are often misapplied' (Abrams, 2010). The absence of dialogue between the groups builds prejudice. In the face of the unbridled spread of pandemic or any other threat to its existence, the society which can be studied as a conglomerate of groups loses its unity. The 'cultural tightness' of the groups is strengthened and each ingroup struggles to maintain a distance from the stigmatized ingroup. They try to affirm their separateness as when the Shia faction of the Indian Muslims declared that they had nothing to do with the 'Tablighi Jamaat'. Essentialization is thus detrimental to the structure of the society and ultimately results in a state of mutual distancing and loss of cohesive behavior.

\section{Role of media in essentializing religion}

'Humanity above religion: Hindu youth comes forward to help Muslim man in violence-hit Delhi' (News Desk, 2020). 'Muslim neighbours help Hindu man's kin conduct his funeral' (Sekar and Naig, 2020). 'Plasma of Muslim can help treat Hindu, says Kejriwal, urges unity in COVID-19 fight'
(PTI, 2020c). "It was the least we could do": When Muslims shouldered a Hindu neighbour's bier in Jaipur' (Sirur, 2020).

It will not be an exaggeration to state that media discourse in India is replete with the Hindu-Muslim binary. The abovequoted news headlines that appeared in print and electronic media in the past few months seem to exhibit a sense of rare fellow feeling between two disparate religious communities. However, this type of news is also indicative of at least two other things: A capacity for dramatic presentation, a journalist's tool, which can captivate the attention of the readers with catchy phrases; and a deep-seated politically charged ambivalence which is integral to the journalists' attempt of shaping the reader's consciousness through a 'climate of opinion' (Mutz, 1989; Sadaf, 2011). If we analyze the first news item, we can discover a contradiction underscoring a paradox of perception. Whereas the first clause asserts the importance of 'humanity' above 'religion', the second clause problematizes the earlier assertion. The two subsets, presumed as binary, 'Hindu' and 'Muslim' are associated in such a way that a humane act of kindness between the groups attains epic proportion. This is where 'essentialising' starts functioning in the public's consciousness and a transition from virtue to utilitarian principle is subtly predicated in the news items. The rest of the news items cited above also function similarly and thereby try to manifest an aura of rarity. The emphasis on subsets 'Hindu' and 'Muslim' and their helping of each other is iterated over and over, like Bhabha's idea of demonic repetition that is anxiously repeated (Bhabha, 1994), only to show the lack thereof, crystallizing the impossibility of erasing the constructed essence of binaries through disparate social identities. To put it succinctly, the two social categories are seen in such a manner that these two communities helping each other are seen as rare and unusual. An inimical essentialization of religion had been done in such a manner that it precludes the 'humanitarian' set and its corresponding virtue (Holtz and Wagnor, 2008). It contrarily creates cultural sets of virtue precluding each other; i.e., Islam and Hinduism become mutually exclusive because they discursively exist as each other's antithesis; though, in reality, the sub-sets ought to be subsumed within the set of humanity. This is the same media that also reports lynching, rape, and other brutalities by tagging religious identities (Siddiqui, 2019, Raj and Nordland, 2019; Khan, 2019; Schultz, 2019). Therefore much of the fixity (in the sense of Bhabha) is constructed by media and other agencies in such a manner as that would benefit the interest of the groups that they serve. Let us consider four different news items published in Al Jazeera that would show how public opinion is guided by the media:

'The Muslim gathering held at the end of last month at a sprawling mosque complex on the outskirts of Malaysia's capital Kuala Lumpur has emerged as a source of hundreds of new coronavirus infections spanning Southeast Asia'(Thian, 2020);

'On any given day, the headquarters of Muslim missionary movement, the 'Tablighi Jamaat', in the narrow lanes of capital New Delhi's Nizamuddin area, is full of activity, with hundreds of worshippers streaming in and out of the five-storey building'(Bisht and Naqvi, 2020);

'India has launched a massive search to track down those who attended an event organised by a Muslim missionary movement after dozens of people test positive for coronavirus and at least seven reportedly die'(MN, 2020);

'Muslims have been attacked after a religious gathering in the capital allegedly led to a rise in coronavirus cases, with 
the minority being blamed for the spread of the disease. $\mathrm{Al}$ Jazeera's Elizabeth Puranam reports from New Delhi' (Puranam, 2020).

(Emphasis added by the author to show how some keywords are repeated throughout in news items).

The trope 'Muslim' is recurrent in all the four news items published on different dates in 2020. The repetition (Anand and Sternthal, 1990, Campbell et al, 2003) of the trope along with the news of coronavirus acts as a qualifier that travels through public consciousness via media and acquires negative priming (Malley and Strayer, 1995; Cushion et al., 2020). In the first three news items, Al Jazeera points out how some Muslims are responsible for contagion in India and abroad. Similar news items have flooded print and electronic media apart from thousands of messages circulated on social networking sites as 'third-person effect' (Mutz, 1989; Tsfati and Cohen, 2013). Interestingly the media which gave the basis of forming a public opinion by linking the virus with religion later runs news on attacks on Muslims, who were alleged to be spreading coronavirus. Eventually, individual/collective acts and the actor's religion become a cognate idea in the society to understand social behavior (Brauer et al., 2013; Corcoran et al., 2017; Ellison and Linda, 1994). In this context, a stereotype image was created with corresponding social behavior by its repeated telecast and reporting in electronic and print media: 'Muslims' became the spreader of coronavirus, and 'Hindus' became persecutors of 'Muslims'. Wagner and Holtz's theory that 'perceived homogeneity within a group results in an increased belief in an underlying essence; and conversely, that the belief in an underlying essence increases the perceived homogeneity of the group' (Holtz and Wagnor, 2008) explains as to why many of the activities committed by an individual or by a group of people are seen through the lens of religion. In the case of 'Tablighi Jamaat', when news published by AlJazeera (Thian, 2020), The Hindu (Trivedi, 2020), and other print and electronic media about the religious congregation and its corresponding effect on contagion surfaced, it had metonymically been associated with the whole of which it had only been part, i.e sub-set projected as a set. 'Tablighi Jamaat' is a subset of the Muslim, and with the help of extended metonymic implication, it came to be projected as only 'Muslim' (Bisht and Naqvi, 2020; Apoorvanand, 2020). Whereas some Muslims objected to the gathering at religious places, the matter-of-fact is also that some did not object, and rather encouraged it (Kumar, 2020). Multiple videos circulated on Facebook and Whatsapp showing some religious leaders challenge 'social distancing' advisory are created consciously to incite a communal conflict in India (Sharma, 2020; Anand, 2020; PTI, 2020d). Between the ones who are responsible and the ones who are not responsible there are borderline cases as well which are quite fuzzy (Putnam, 1975). The majority of the population belongs to this fuzzy border who may have no role but are implicated and eventually exploited by opposing factions to feed their socio-political interest. Although 'Tablighi Jamaats' were responsible for spreading contagion unknowingly in many South Asian countries including India, Pakistan, and Malaysia (Biswas and Sultana, 2020); it is only in India that it took a communal turn. The claim about Corona-jihad is not only preposterous, baseless, and politically motivated but is also to be read as a part of a conspiracy theory. This needs to be critically examined in the context of national and international politics to understand the dynamics of power and inter-group relationship, which is beyond the purview of this paper. However, one question has to be pertinently asked as to why the 'Tablighi Jamaat' did not take the call for the greater good of mankind when many of the Arabian and Islamic countries had closed down their religious places and prohibited mass gathering (Ozalp, 2020)? It is true that 'Tablighi Jamaat' doesn't represent entire Islam, but the insistence on offering prayers at Mosques by a certain section of people by violating social distancing norms had greater implications (Hindustan Times, 2020, 26 March). First, it came to be viewed as the audacity of a group that tried to challenge the advisory issued by the State; and secondly, it came into a confrontation with the majority caste Hindu by engaging into a verbal spat in social networking platforms like Facebook and Twitter (Ellis-Petersen and Shaikh, 2020; Mander, 2020). This gave an opportune moment to polarizing forces to create a plausible image of corona-jihad, not meant to be necessarily correct, (just like an angry and gun yielding Muslim; India as Lynchisthan, etc.) (Wagner et al., 2020), and where the global 'socio-political antagonism' can be recast in cultural terms (Semati, 2010). The action of 'Tablighi Jamaat' unfortunately became the essence of Islamic action.

There had been sufficient research to prove that religious association not only controls but also diminishes criminal activities (Adamczyk et al., 2017; Baier and Wright, 2001). However, in the present context, the activities of 'Tablighi Jamaat' had been labeled with criminal conspiracy by some media houses and political groups (Biswas and Sultana, 2020). Although this remains a matter of religious controversy, yet the video clippings where some members from the Muslim community have claimed that a truly religious person will not be affected by a virus, just like some Hindus claiming that cow-urine can ward off the virus (PTI, 2020a) truly show their ignorance. These preposterous claims remind us of the dawn of a dark age where a scientific and rational point of view is bulldozed by irrational interpretations of obdurate religious views. The world of nature seems to be blanketed by the world of culture, where culture assumes the role of nature.

Essence belongs to the realm of nature, but reimaging essence within the realm of culture not only alters the essence of essence itself but also gives scope for manipulation of the essence. It fractures the possibility of social cohesion. It is a very sophisticated process as the essentializing process by ingroup ends up in the essentialization process of outgroups. To contextualize it, in the case of the 'Tablighi Jamaats' and some leaders from the Muslim community, their rejection of the government's advisory on social distancing as a ploy, and insistence on assembling in Mosques became a part of their religious essence. This essentializing allowed the outgroup to read defiance as anti-state and a part of corona-jihad, thereby adding a new feature to the constructed essence by an out-group. But the question arises as to if govt advisories relating to 'social distancing' were violated, why assign a religious tag to it? They were violated by all kinds of people. In a democratic society, a state cannot be in complete control of individual choices. Secondly, ignorance and irrational behavior are also a matter of personal choice, and bringing in religion as a concomitant to explain such behavior indicates a cultural-ideological outlook underscoring a political nature of projection leading to xenophobia (Semati, 2010). This is again to be understood in the context of international politics and orientalist projection of Other in Edward Said's two important books according to Semati: Orientalism and Covering Islam: How the Media and the Experts Determine How We See the Rest of the World, which explain the role of media in creating and constructing essence. The demonization of Islam and rise in Islamophobia had been largely created by some western powers, through media (Semati, 2010), as a political strategy. This strategy got a similar footing when the media reported the cause-effect relationship vis-a-vis 'Tablighi Jamaat' and COVID-19. As media has the potential in shaping ideological battles, the public is prone to get affected by what is shown in media (Eid, 2014; Wagner et al., 2020). Although all the contents in media are not accepted 
uniformly always (Happer and Philo, 2013; Tsfati and Cohen, 2013), yet witnessing a socio-political situation in India, when 'Tablighi Jamaat' was accused of spreading 30\% of the COVID 19 cases in India, it became easier for divisive forces to add a communal color to it (PTI, 2020, 2020b) giving rise to stigma and fear in the affected communities.

\section{Stigma and fear during the pandemic}

Stigma was originally a classical Greek term for a permanent mark that branded a person as a criminal, traitor, or slave. In recent times the word stigma has been used to describe the process of negative discrimination against people with certain physical, behavioral, or social attributes (Barrett and Brown, 2008). This discrimination has been present in medical sciences and has come up time and again in case of diseases like AIDS whereby certain communities are marked as more prone to infection and also as the source of contamination. Criminal intent is also attributed to this belief. However, it is not just limited to AIDS. It is also visible in the case of infectious diseases. In many countries stigma about Hansen disease and leprosy is worse than the disease itself (Waxler, 1992). Farmer and Kleinman explored these dynamics in the early years of the HIV/AIDS pandemic and traced the suffering of AIDS patients and their families. They had to face socioeconomic inequalities compounded by inappropriate use of resources, magnified by discrimination, augmented by fear, and amplified by the loss of social identity (Farmer and Kleinman, 1989).

Understanding stigma and talking about it concerning infectious disease becomes crucial because it can lead to impediments to quick detection of diseases and treatment as well. It can reduce early detection and treatment and lead to aggravation of the disease. It can also make a certain marginalized section of the people more susceptible to the disease owing to their systemic exclusion from proper health care. As mentioned in the introduction to this paper, Critical Race Theory investigates how external attributes are assigned to certain groups of people quite arbitrarily. This enables the hegemonic group to have control over the essentialized group through their projection of inferiority and vulnerability. This form of discrimination and eventual subjugation was not only prevalent in ancient India, but it is also visible in more subtle forms in the present times around the world. There are many instances whereby stigmatized people become suspicious of health workers and administration thereby leading to the wrong perception of the disease (Barrett and Brown, 2008). This has been proven by many instances during health emergencies. Be it AIDS or Ebola, such stigma and fear around the diseases have created more problems for both the patients, as well as caregivers. (Wester and Giesecke, 2018; Castro and Farmer, 2005; Strong and Schwartz, 2019; Ullah, 2011). ${ }^{2}$

Culture-centered approaches have also been used in addressing this kind of stigma during pandemics. Culture-centered approaches mean working from within a culture to identify the health issues that a community considers important. This is further effective in case of health conditions like obesity, hypertension, etc. which may be non-communicable but are lifestyle diseases and hence is related to communities' livelihood and cultural choices (Dutta, 2007). To address these issues, Airhihenbuwa (1995) developed the PEN-3 model based on a culture-centered approach. The model consists of three primary domains: a) Relationships and Expectations (RE) focussing on Perceptions, Enablers and Nurturers b) Cultural Empowerment (CE) including Positive, Existential and Negative and c) Cultural Identity (CI) focussing on the Person, Extended Family or Neighborhood (Airhihenbuwa, 1995). This model has been followed to understand the impact of outbreaks and mitigate such impacts. It has also been a guiding factor in developing culturally focussed health interventions (Airhihenbuwa and Iwelunmor, 2012). This model has been used to explore management of type 2 diabetes (Barbara, Krass, 2012), perception of HIV stigma (Okoror, Belue, et al., 2014), knowledge and belief about cervical cancer screening in Ghana (Williams and Amoateng, 2012), in diabetes prevention intervention (Cowdery et al., 2010)

This approach becomes crucial for developing and underdeveloped countries facing the problem of less funding in public health. ${ }^{3}$ In such a situation taking families and the community on board will ensure proper screening. This was evident even during the outbreak of COVID-19 in India. Monson talks about how the 2014 Ebola outbreak was reported by American media. While the interest initially was limited to sensational news, once the first patients reached the US soil, the attitude towards the disease changed. African Americans came to be seen as potential carriers of the disease. The entire continent of Africa was portrayed as a single Ebola-hit country even though it originated in Zaire for the first time and was restricted to only some countries. Even political leaders in America wanted to cancel flights from Africa creating a panicky situation in the continent. Ebola was essentially seen as African (Monson, 2017).

Fear and stigma during COVID-19: the Indian scenario. The first case of COVID-19 was detected in India on 30th January 2020. However, the country delayed any strict response as there were no clear guidelines from the World Health Organisation. It was as late as 11th March that COVID-19 was declared a pandemic and India went for a nationwide complete lockdown from 24th March 2020 (Cucinotta and Vanelli, 2020). From the initial days of lockdown, there were multiple challenges in front of the country. The lockdown was violated the very next day when thousands of migrant laborers went out in the streets of Delhi demanding to go home.

Apart from this, the fear and stigma attached to this highly contagious disease have made it difficult to detect it on time. Doctors have been emphasizing the need for timely detection to improve the mortality rate. In the case of HIV also it was evident that stigma and misinformation prevented people from seeking medical care until it was too late (Madiba and Mokgatle, 2017; Churcher, 2013; Golub and Gamarel, 2013). This was visible in the case of other infectious diseases like Tuberculosis and SARS (Person et al., 2004; Baldassarre et al., 2020). In the case of COVID-19 unwarranted behavior towards health workers, infected persons and their families, certain ethnicities and anyone with any kind of connection with the disease were evident from the very beginning (Devi, 2020; Saikia, 2020).

Actors who are indulged in this stigmatization include the larger community. In India, patients were stamped with "COVID-19 Positive" mark (Mehra, 2020). This in many cases led to alienation and social boycott of families of the infected person. There were also cases when entire villages were cut off if anybody from that area tested COVID-19 positive. Roads were dug up so that vehicles from that village cannot ply to other areas. But this also meant that essential services like ambulances, food items could not enter the village in times of need (Kumar, 2020).

This stigma was further exacerbated by the media, social media, and a section of the political class. Two incidents show how the media played a role in fear-mongering and creating a stigma around the disease. The first was the Tablighi Jamaat congregation at Delhi which was shown as an act of calculated conspiracy instead of carelessness. The participants were shown as superspreaders and media played a crucial role in vilifying the participants. This was followed by a large number of fake news and videos being circulated which showed Muslims deliberately spreading the infection (Sharma and Gupta, 2020). Second, 
certain organizations affiliated with different political parties were consciously spreading fake news (Yadav, 2020).

India: a fertile ground? Fear and stigma are not uncommon during pandemics. Starting from the Spanish Flu of 1918 to the avian flu in recent times fear and stigma became a bigger problem in societies rife with deep social chasms (Barrett and Brown, 2008). In India, communal polarization is not new either. Since independence political mobilization has happened on communal and caste lines. Community and caste-based mobilization become a problem when certain communities and castes become more susceptible to vilification during pandemics. This was evident during the COVID-19 outbreak which saw a marginalized section of people at the receiving end of negative stereotyping. This became explicit when the Tablighi Jamaat incident occurred. Communal vilification took place at different levels and the entire Muslim community was held responsible for the fault and mistake of a few. Fake news and videos were circulated to support that theory. This was further fed into the narrative that Muslims are perennially disloyal to the country.

Along with Muslims, people belonging to financially weaker sections, Scheduled Castes, or Dalits also faced similar atrocities according to media reports. According to a Madurai-based NGO Evidence, 30 cases of caste-based violence have been reported from Tamil Nadu alone. It was reported that upper caste men have placed thorns outside the homes of Dalits to make sure that they do not move out (Newsclick Report, 2020). Social and physical distancing has been espoused by the World Health Organisation as an important aspect to contain the spread of the virus. For many, this has vindicated the age-old caste-based discrimination that existed in India. While social distancing talks about maintaining a physical distance between two individuals, many tried to recreate a hierarchical connotation and supported a biased treatment towards Dalits (Rani, 2020). There were news reports that showed sanitation workers being attacked on the suspicion of spreading the virus. (Hindustan Times, 18 April 2020)

In many quarantine centers, people refused to take food cooked by Dalits. When people from the Dalit communities were quarantined, in some places they were made to clean the toilets. From the Yadani community (waste picker and drain cleaning community) of Andhra Pradesh which has been barred from purchasing essentials such as food and medicine by their upper caste locales to children of Musahar community of Varanasi sustaining on grass, the impact of the lockdown has been lopsided (Ratan, 2020). Adding to this milieu, the problem of lack of education and scientific temperament became visible. This becomes clear in the sharp contrast to how the crisis has been managed across states. Kerala was the first state to detect a case of COVID-19. But the state could tackle the pandemic owing to its participatory governance nurtured through generations of crosssectoral dialogs. Multiple stakeholders are taken on board like noted academicians, youth organizations, women, farmers, etc. People's Plan Movement (1996-1997) brought together social and political democratic ideals within the framework of local selfgovernance (Mohanakumar, 2003). Kerala prepared for this COVID-19 response based on its experience of dealing with two crises back to back-the Nipah outbreak and floods-both in 2018. Kerala's literate population with a culture of rationalism did not succumb to fake news and rumors around the disease. The Kerala government also took the initiative to set up the Institute of Advanced Virology at Alapuzzha to ensure speedy testing. People voluntarily co-operated with the state machinery and succeeded in reducing contamination ensuring a good recovery rate. The Kerala Chief Minister also took on board different religious heads and all kinds of religious congregations were regulated, canceled, or postponed. All this again showed the efficiency of the decentralized Kerala model with a strong focus on the public health and education sector (Roy, Dave, 2020). A similar mechanism was also initiated in Assam by the tireless effort of the Health Minister Dr. Hemanta Biswa Sarma which helped in containing the spread of COVID-19.

Fear, stigma and treatment delays: the vicious circle. Unfounded fear and stigma during a pandemic have serious connotations. This practice not only carries a risk to the health and wellbeing of the marked communities but also the overall mechanism of countering the disease and reducing its impact. Fear and stigma of being isolated and socially boycotted led many people to conceal their travel history to hotspots. When Tablighi Jamatis was requested to come out to get voluntarily tested, many delayed further increasing the risk of infecting others. ${ }^{4}$ (Bisht, Naqvi, 2020; Hindustan Times, 2020; Kartikeyan, 2020).

In several instances, health workers were attacked at different places. In most of the cases, the attacks were instigated by fake rumors circulating on social media that people from the minority community will be taken to the quarantine centers and infected (The Wire Staff, 2020). The lack of information and scientific temper, as well as deep-rooted communal polarization, made people believe such claims that led to attacks on health workers and police personnel. In Assam instances of quarantined people regularly flouting covid-19 protocols were witnessed because of unscientific temperament and ignorance (The Telegraph, 2020).

Political leaders also get an opportunity to indulge in populist politics. This has been evident across the world from Bolsonaro in Brazil to right-wing leaders in East European countries. Prasad believes that in India, the reigning Bharatiya Janata Party's (BJP) populist leaders have crafted certain strategies and discourses in the garb of countering the virus but in reality pushing the party's longstanding political agenda of Hindutva politics (Prasad, 2020). Kapil Mishra, a BJP leader tweeted that Tabligh Jamaat members were spitting on doctors and other health workers. He claimed that they aimed to infect as many people as possible with coronavirus (Ellis-Peterson and Shaikh, 2020).

Excessive emphasis on marking certain communities as scapegoat forecloses a rational approach towards countering a pandemic. Stakeholders like the media and the larger community should hold governments accountable if they fail to provide proper public health facilities. Instead, fake news, rumors, and vilification of certain communities lead to diversion from real issues increasing the negative impact of a pandemic manifold.

\section{Conclusion}

The COVID-19 has posed a serious threat to mankind. It is one of the biggest pandemics of the century till now and we are not aware of how more such pandemics are awaiting mankind in the future. World Health Organization, which is closely monitoring the situation, has appealed to the countries of the world to share their respective research findings so that a collective and conscientious effort can be put to fight the pandemic. Furthermore, the WHO has also appealed that it is the time for facts, science, and solidarity and not fear, rumor, or stigma. Nevertheless, we see that world leaders and community leaders are constantly engaged in vilification based on race, community, and nation. Names like Spanish-flu, Chinesevirus, or corona-jihad are not only misnomers but also socially debilitating with a long-term mental and political ramification. Such adjectives not only attribute negative essence to communities, races, and nations but also belittle their human essence. It is seen that the media and social networking sites have been used as tools to inflict mental and social wounds on such communities, especially in India. Whereas Media is considered the fourth pillar of democracy, it has 
been witnessed that more often than not they become the handmaid of the political forces. Media should not only maintain objectivity in airing the news but also must understand their social responsibility in maintaining peace and harmony in society. Instead of airing news that may create fissures in social relations, they must focus on constructive criticism instead of provocative criticism. However, in recent times they seem to become a factor in essentializing social groups which has a detrimental effect on society. This kind of essentialization not only creates fissures in the society but also creates additional hurdles for social institutions to fight the crisis of pandemic as seen from the discussion above. Instead of considering the entire mankind as one ingroup with a common objective of humanity and humane essence, our petty political outlook enslaves us in smaller outgroups within dark cells of prejudice and selfishness. The cause of the rise in COVID-19 cases in India can be attributed to such narrow politics based on essentializing race, religion, and culture. The stigma and fear which had aggravated the problem in India could have otherwise been contained with a cohesive and collective effort emanating from the solidarity of various socio-religious groups and communities. This episode leaves us with sufficient scope to rethink and reconfigure our social structure and outlook based on more holistic humane essence than on a diminutively constructed cultural essence. Furthermore, there is also a scope to investigate how social media like Facebook, blogs, and Twitter have impacted the lives of people during this pandemic. As this research was limited to the analysis of how media and political groups essentialized religion, it did not take into account the role of hate messages in social media.

\section{Data availability}

Data sharing not applicable to this article as no datasets were generated or analyzed during this study.

Received: 3 July 2020; Accepted: 13 May 2021;

Published online: 31 May 2021

\section{Notes}

1 In India, structural discrimination is pronounced more in the form of caste or religious differences.

2 Many a time health care providers also face stigma for being potential carriers.

3 Third world countries spend a very small part of their budget on public health. Using a model that emphasises informal structures and associations like extended family and health care personnel already working at the ground level will not put an extra burden on the budget.

4 The incident at Tablighi Jamaat was criminalised and the infected people were treated as criminals. Fearing the stigma attached to the disease, many returnees from Tablighi jamaat in Assam did not disclose their travel details and this led to a spread of infection to immediate family members of those people. The government of the state initially threatened with legal action but later reached out to community leaders to give the details of such returnees to curtail the further spread.

\section{References}

Abrams D (2010) Processes of Prejudice: Theory, Evidence and Intervention. Centre for the Study of Group Process, University of Kent. www. equalityhumanrights.com

Adamczyk A, Freilich JD, Kim. C (2017) Religion and crime: a systematic review and assessment of next steps. Sociol Religion 78(2):192-232. https://doi.org/ $10.1093 /$ socrel/srx012

Agadullina E, Lovakov A (2017) Understanding entitativity: are there real differences between approaches? Psychology https://doi.org/10.17323/1813-89182017-3-536-554

Airhihenbuwa CO (1995) Health and culture: beyond the western paradigm. Sage, Thousand Oaks. New Delhi

Airhihenbuwa CO, Iwelunmor JI (2012) Why Culture Matters in reducing the dual burden of communicable and non-communicable diseases: linking noncommunicable and communicable diseases. The Commonwealth Health
Ministers Meeting, Geneva, Switzerland. http://www.chpa.co/Documents/ WhyCultureConnects-DrAirhuhenbuwa.pdf. Accessed 11 Sep 2020

Anand A (2020) Pakistan trying to 'influence' Indian Muslims to violate the COVID-19 lockdown: Delhi Police. The Print, 4 April. https://theprint.in/ india/pakistan-trying-to-influence-indian-muslims-to-violate-the-COVID19-lockdown-delhi-police/395312/ Accessed 15 Sep 2020

Anand P, Sternthal B (1990) Ease of Message Processing as a Moderator of Repetition Effects in Advertising. J Market Res 345-353. https://doi.org/10.1177/ 002224379002700308

Apoorvanand (2020) How the coronavirus outbreak in India was blamed on Muslims. Al Jazeera, 18 April. https://www.aljazeera.com/indepth/opinion/coronavirusoutbreak-india-blamed-muslims-200418143252362.html Accessed 15 Sep 2020

Baier CJ, Wright BRE (2001) 'If you love me, keep my commandments': a metaanalysis of the effect of religion on crime. J Res Crime Delinquency 38 (1):3-21. https://doi.org/10.1177/0022427801038001001

Baldassarre A, Giorgio G, Alessio F (2020) Stigma and Discrimination(SAD) at the time of SARS-COV-2 Pandemic. Int J Environ Res Public Health 17(17): https://doi.org/10.3390/ijerph17176341

Balibar E, Wallerstein I (1988) Race, nation, class ambiguous identities. Trans. Chris Turner. Verso, New York

Barbara S, Krass I (2012) Self Management of Type 2 Diabetes by Maltese Immigrants in Australia: can community pharmacies play a supporting role? Int J Pharmacy Practice 21(5):305-313. https://doi.org/10.1111/ijpp.12011

Barrett R, Brown PJ (2008) Stigma in the Time of Influenza: social and institutional responses to pandemic emergencies. J Infect Dis 197(1):34-37. https://www. jstor.org/stable/30086991

Bhabha HK (1994) The other question: stereotype, discrimination and other discourse of colonialism. The Location of Culture. Routledge, London, pp. 94-120

Bisht A, Naqvi S (2020) How Tablighi Jamaat Event Became India's Worst Corona Vector?. Al Jazeera. Available at https://www.aljazeera.com/news/2020/4/7/ how-tablighi-jamaat-event-became-indias-worst-coronavirus-vector

Biswas D, Sultana P (2020) Policing: a Journal of Policy and Practice Oxford University Press 14:1104-1111. https://doi.org/10.1093/police/paaa024

Brauer JR, Tittle CR, Antonaccio O (2013) Does religion suppress, socialize, soothe, or support? Exploring religiosity's influence on crime. J Scient Study Religion 52:753-74. https://doi.org/10.1111/jssr.12063

Campbell DT (1958) Common fate, similarity, and other indices of the status of aggregates of persons as social entities. Behav Sci 3:14-25

Campbell MC, Keller KL (2003) Brand familiarity and advertising repetition effects. J Consumer Res 3(2):292-304. https://doi.org/10.1086/376800

Castro A, Farmer P(2005) Understanding and addressing AIDS-related stigma: from anthropological theory to clinical practice in Haiti Am J Public Health 95(1):53-59. https://doi.org/10.2105/AJPH.2003.028563

Churcher S (2013) Stigma related to HIV and AIDS as a barrier to accessing healthcare in Thailand: a review of recent literature. South East Asia J Public Health 2(1):12-22. https://doi.org/10.4103/2224-3151.115829

Corcoran KE, Pettinicchio D, Robbins. B (2017) A double-edged sword: the countervailing effects of religion on cross-national violent crime. Social Science Quarterly 99:377-89. https://doi.org/10.1111/ssqu.12408

Cowdery J, Parker E, ShandownAmy T (2010) Application of the PEN-3 model in a diabetes prevention intervention. J Health Disparities Res Practice 4 (1):26-41. https://digitalscholarship.unlv.edu/jhdrp/vol4/iss1/3/

Cucinotta D, Vanelli M (2020) WHO declares COVID-19 a pandemic. Acta Biomed 91(1):157-160. https://doi.org/10.23750/abm.v91i1.9397

Cushion S, Lewis J, Kilby A (2020) Why Context, Relevance and Repetition Matter in News Reporting: Interpreting the United Kingdom's Political Information Environment. Journalism 21(1):34-53. https://doi.org/10.1177/1464884917746560

Delgado R, Stefancic J (2016) Critical Race Theory: An Introduction. New Delhi: Dev Publishers and Distributors

Denson TF, Lickel B, Mathew C, Douglas MS, Daniel RA (2006) The roles of entitativity and essentiality in judgements of collective responsibility. Group Proces Intergroup Relations 9(1):43-61. https://doi.org/10.1177/1368430206059857

Devi S (2020) COVID-19 exacerbates violence against health workers. Lancet 396:10252. https://doi.org/10.1016/S0140-6736(20)31858-4

Dutta MJ (2007) Communicating about culture and health: theorizing culturecentered and cultural sensitivity approaches. Commun Theory 17:304-328 https://doi.org/10.1111/j.1468-2885.2007.00297.x

Eid M (2014) Perceptions about Muslims in Western Societies. In:Eid M, Karim $\mathrm{KH}$ (ed). Re-imagining the other. Palgrave Macmillan, New York

Ellison CG, Linda KG (1994) Religious Involvement, Social Ties, and Social Support in a Southeastern Community. J Sci Study Religion 33:46-61

Ellis-Petersen H, Shaikh AR (2020) Coronavirus Conspiracy Theories targeting Muslims Spread in India. The Guardian, 13 April. Available at https://www. theguardian.com/world/2020/apr/13/coronavirus-conspiracy-theoriestargeting-muslims-spread-in-india

Farmer P, Kleinman A (1989) AIDS as human suffering. Daedalus 118(2):135-160. Accessed 18 May 2020. https://www.jstor.org/stable/20025240 
Geertz C (1993) Religion as a cultural system. The interpretation of Cultures: Selected Essays, 87-125. Basic Books. The USA. https://monoskop.org/images/ 5/54/Geertz_Clifford_The_Interpretation_of_Cultures_Selected_Essays.pdf

Golub SA, Gamarel KE (2013) The Impact of Anticipated HIV Stigma on Delays in HIV Testing Behaviors: findings from a community based sample of men who have sex with men and transgender women in New York. AIDS Patient Care STDS 27(11):621-627. https://doi.org/10.1089/apc.2013.0245

Happer C, Philo G (2013) The role of the media in the construction of public belief and social change. J Soc Political Psychol 1(1):321-336. https://doi.org/ 10.5964/jspp.v1i1.96

Haslam N (2006) Dehumanization: an integrative review. Personal Soc Psychol Rev 10(3):252-264

Hindustan Times. (2020). COVID-19: Men exiting mosque thrashed by cop for violating lockdown order. Youtube, 26 March. https://www.youtube.com/ watch?v=snMl0XcSzOU Accessed 15 Sep 2020

Holtz P, Wagner W (2008) Essentialism and attribution of monstrosity in racist discourse: right-wing internet postings about Africans and Jews. J Communit Appd Soc Psychol 18:1-15. https://doi.org/10.1002/casp.1005

Huntington SP (1996) The clash of civilizations and the remaking of the world order. Simon \& Schuster, New York

Jackson JC, M van Egmond et al. (2019) Ecological and cultural factors underlying the global distribution of prejudice. PLoS ONE 14(9): https://doi.org/10.1371/ journal.pone.0221953

Kartikeyan S (2020) Assam Police nab 12 Markaz attendees hiding in different mosques; sent to quarantine", Republicworld.com, April 13, 2020. Available at https://www.republicworld.com/india-news/general-news/assam-police-nab12-markaz-attendees-hiding-in-differentmosques.html

Kashima Y (2004) Culture, communication, and entitativity: a social psychological investigation of social reality. In: Yzerbyt V, Judd CM, Corneille O (eds) The psychology of group perception: perceived variability, entitativity, and essentialism. Psychology Press, New York, pp. 257-273

Kello K (2017) Identity and othering in past and present: representations of the Soviet Era in Estonian post Soviet textbooks. J Soc Polit Psychol 5 (2):665-693. https://doi.org/10.5964/jspp.v5i2.737

Khan OF (2019) 13-year-old Hindu girl raped in Pakistan, 2 held. The Times of India, 9 June. https://timesofindia.indiatimes.com/world/pakistan/minorhindu-girl-intoxicated-and-raped-in-pakistan/articleshow/69707638.cms Accessed 15 Sep 2020

Kumar A (2020) Tablighi Jamaat' episode | Muslims fear more 'social distancing. The Hindu, 2 April. https://www.thehindu.com/news/national/other-states/ muslims-fear-more-social-distancing/article31231474.ece. Accessed 15 September 2020

Kumar, KS (2020, 27 March). No Way In, No Way Out: Locals Block Village Roads. The New Indian Express. https://www.newindianexpress.com/states/ karnataka/2020/mar/27/no-way-in-no-way-out-locals-block-village-roads2122090.html Accessed 15 Sep 2020

Locke J (1689) An essay concerning human understanding. Clarendon Press, Oxford, 1975

Madiba S, Mokgatle M (2017) Fear of Stigma, Beliefs and Knowledge about HIV are barriers to early access to HIV testing and disclosure for perinatally infected children and adolescents in rural communities in South Africa. South African Family Practice 59(5):175-181. https://doi.org/10.1080/ 20786190.2017.1329489

Malley GB, Strayer DL (1995) Effect of stimulus repetition on positive and negative identity priming. Percept Psychophys 57(5):657-667. https://link.springer. com/content/pdf/10.3758/BF03213271.pdf

Mander H (2020) The Coronavirus Has Morphed Into an Anti-Muslim Virus. The Wire, 13 April. https://thewire.in/communalism/coronavirus-anti-muslimpropaganda-india Accessed 15 September 2020

Mehra C (2020, 17 April). Covid 19 stigma is a major roadblock in India's path to recovery: Here's How to Beat It. Scroll.in. https://scroll.in/article/959153/ COVID-19-stigma-is-a-major-roadbloack-in-indias-path-to-recovery-hereshow-to-beat-it Accessed 15 Sept 2020

Mill JS, Bentham J (1987) Utilitarianism and Other Essays. Penguin Books

MN P (2020) India tracks attendees after Muslim event linked to virus cases. Al Jazeera, 31 March. https://www.aljazeera.com/news/2020/03/india-linksdozens-coronavirus-cases-muslim-gathering-200331095417048.html Accessed 21 July 2020

Mohanakumar S (2003) Decentralisation in Kerala: people's plan. Economic Political Weekly 38(30):3214-16. https://www.epw.in/journal/2003/30/discussion/ decentralisation-kerala-peoples-plan.html Accessed 20 May 2020

Monson S (2017) Ebola as African: American Media Discourse of Panic and Otherization. Africa Today 63(3):3-27. https://doi.org/10.2979/africatoday.63.3.0. Mobilizing Musical Performance and Expressive Culture in Ebola 2014 Epidemic

Mutz DC (1989) The influence of perceptions of media influence: third person effects and the public expression of opinions. Int J Public Opinion Res 1 (1):3-23. https://doi.org/10.1093/ijpor/1.1.3
News Desk (2020) Humanity above religion: Hindu youth comes forward to help Muslim man in violence-hit Delhi. India Tv, 26 February. https://www. indiatvnews.com/news/india/hindu-youth-helps-muslim-man-in-northeastviolence-hit-delhi-bhajanpura-chowk-592659 Accessed 21 July 2020

Newsclick Report (2020, 13 May) TN: At least 30 major incidents of Caste-based violence during Lockdown, Says Study. The Newsclick. https://www. newsclick.in/Tamil-Nadu-Caste-Based-Violence-COVID-19-Lockdown Accessed 21 July 2020

Okoror T, Belue R, Zungu N, Adams A, Airhihenbuwa CO (2014) HIV positive women: perceptions of Stigma in Healthcare setting in Western Cape, South Africa. Health Care Women Int 35(1):27-49. https://doi.org/10.1080/ 07399332.2012 .736566

Ozalp M (2020) How coronavirus challenges Muslims' faith and changes their lives. The Conversation, 2 April. https://theconversation.com/how-coronaviruschallenges-muslims-faith-and-changes-their-lives-133925 Accessed 21 July 2020

Person B, Sy F, Holton K, Govert B, Liang A, NCID/SARS Emergency Outreach Team (2004) Fear and stigma: the epidemic within the SARS outbreak. Emerg Infect Dis 10(2):358-363. https://doi.org/10.3201/eid1002.030750

Prasad A (2020 The Organisation of Ideological Discourse in Times of Unexpected Crisis: Explaining how COVID-19 is Exploited by Populist Leaders. Leadership 0(0):1-9. https://journals.sagepub.com/doi/10.1177/1742715020926783 24 September 2020

PTI (2020a) Coronavirus: Group hosts 'cow urine party', says COVID-19 due to meat-eaters. The Hindu, 14 March. https://www.thehindu.com/news/ national/coronavirus-group-hosts-cow-urine-party-says-COVID-19-due-tomeat-eaters/article31070516.ece Accessed 2 Aug 2020

PTI (2020b) Raghuram Rajan cautions against giving communal colour to coronavirus. The Economic Times, 22 April. https://economictimes.indiatimes. com/news/politics-and-nation/raghuram-rajan-cautions-against-givingcommunal-colour-to-coronavirus/articleshow/75278260.cms? from $=\mathrm{mdr}$ Accessed 2 August 2020

PTI (2020c) Plasma of Muslim can help treat Hindu, says Kejriwal, urges unity in COVID-19 fight. The Print, 26 April. https://theprint.in/india/plasma-ofmuslim-can-help-treat-hindu-says-kejriwal-urges-unity-in-COVID-19-fight/ 409289/ Accessed 2 Aug 2020

PTI (2020d) Report finds bulk video posts on social media to influence Muslim against COVID-19 precautions. Tribune India, 3 April. https://www.tribuneindia.com/ news/nation/report-finds-bulk-video-posts-on-social-media-to-influencemuslim-against-COVID-19-precautions-65069 Accessed 2 Aug 2020

Puranam E (2020) India Muslims targeted in attacks over Coronavirus. Al Jazeera 2 May. https://www.aljazeera.com/news/2020/05/india-muslims-targetedattacks-coronavirus-200502141834870.html Accessed 2 August 2020

Putnam H (1975) The Meaning of 'Meaning'. University of Minnesota Press, Minneapolis

Quine WV (1969) Natural kinds. In: Quine WV (ed). Ontological relativity and other essays. Columbia University Press, New York, pp. 114-138

Raj S, Nordland R (2019) Forced to Chant Hindu Slogans, Muslim Man Is Beaten to Death in India. The New York Times, 25 June. https://www.nytimes.com/2019/ 06/25/world/asia/india-hindu-muslim-beating.html Accessed 2 Aug 2020

Ramlan TE, Hakim N (2016) The Concept of Jihad in Islam IOSR. J Humanit Soc Sci 21(9):35-42. http://www.iosrjournals.org/iosr-jhss/papers/Vol.\%2021\% 20Issue9/Version-7/F2109073542.pdf

Rani J (2020, 14 April) An invisible virus highlights the virulence of an age old virus. The Wire. https://thewire.in/caste/coronavirus-caste-discrimination-india Accessed 2 Aug 2020

Ratan A (2020, 30 April) COVID-19: How casteist is this pandemic? Feminism in India. https://feminisminindia.com/2020/04/30/COVID-19-casteist-pandemic/

Roy A, Dave SK (2020) When People and Governments Come Together: Analysing Kerala's Response to the COVID-19 Pandemic. Econom Political Weekly 55 (18):10-13. https://www.epw.in/journal/2020/18/commentary/when-peopleand-governments-come-together.html

Sadaf A (2011) Public perception of media role. Int J Humanit Soc Sci 1(5):228-236

Sahin M (2018) Essentialism in philosophy, psychology, education, social and scientific scopes. J Innovat Psychol Educ Didactic 22:2

Saikia A (2020) The Other Virus: Hate Crimes Against India's Muslims are Spreading with Covid 19. The Scroll.in. 08 April 2020. https://scroll.in/article/ 958543/the-other-virus-hate-crimes-against-indias-muslims-are-spreadingwith-COVID-19 Accessed 2 Aug 2020

Schultz K (2019) Indian Court Convicts 6 Hindus in Rape and Murder of Muslim Girl, 8. The New York Times, 10 June. https://www.nytimes.com/2019/06/10/ world/asia/india-muslim-girl.html. Accessed 2 Aug 2020

Sekar S, Naig U (2020) Muslim neighbours help Hindu man's kin conduct his funeral. The Hindu, 20 April. https://www.thehindu.com/news/national/ tamil-nadu/muslim-neighbours-help-hindu-mans-kin-conduct-his-funeral/ article31383942.ece Accessed 2 Aug 2020

Semati M (2010) Islamophobia, culture and race in the age of empire. Cultural Stud 24(2):256-275. https://doi.org/10.1080/09502380903541696 
Semati M (2011) Communication, culture and essentialised Islam. Commun Stud 62(1):113-126. https://doi.org/10.1080/10510974.2011.540975

Sharma A, Gupta C (2020, 27 April) Audit of Bigotry: How Indian Media vilified Tablighi Jamaat over Coronavirus Outbreak. Newslaudry. https://www. newslaundry.com/2020/04/27/audit-of-bigotry-how-indian-media-vilifiedtablighi-jamaat-over-coronavirus-outbreak Accessed 2 Aug 2020

Sharma N (2020) TikTok, WhatsApp Videos Being Used To Mislead People On Coronavirus: Cops. NDTV, 3 April. https://www.ndtv.com/india-news/ coronavirus-india-tiktok-whatsapp-videos-being-used-to-mislead-people-oncoronavirus-say-police-2205317 Accessed 2 Aug 2020

Siddiqui Z (2019) Protests in Indian cities after Muslim man is lynched, Modi says he is 'pained'. Reuters, 26 June. https://www.reuters.com/article/us-indiaprotests-lynching/protests-in-indian-cities-after-muslim-man-is-lynchedmodi-says-he-is-pained-idUSKCN1TR2AG Accessed 2 Aug 2020

Sirur S (2020) 'It was the least we could do': When Muslims shouldered a Hindu neighbour's bier in Jaipur. The Print, 14 April. https://theprint.in/india/itwas-the-least-we-could-do-when-muslims-shouldered-a-hindu-neighboursbier-in-jaipur/401182/ Accessed 2 Aug 2020

Stangor, Charles (2014) Principles of Social Psychology - 1st International Edition. Edited by Jhangiani, R. and H. Tarry. Victoria, B.C.: BCcampus. https:// opentextbc.ca/socialpsychology/

Strong AE, Schwartz DA (2019) Effects of the West African Ebola Epidemic on Health Care of Pregnant Women: Stigmatization With and Without Infection. In:Schwartz D, Anoko J, Abramowitz S (eds) Pregnant in the Time of Ebola. Global Maternal and Child Health (Medical, Anthropological, and Public Health Perspectives). Springer, Cham

The Telegraph (2020, 23 May) Warning to Quarantine Norm Violators in Assam. The Telegraph. https://www.telegraphindia.com/states/north-east/coronavirusoutbreak-warning-to-quarantine-norms-violators-in-assam/cid/1775048 Accessed 2 August 2020

The Wire Staff (2020, 3 April). Fake Whatsapp Videos Behind Attack on Health Workers in Indore: Report. The Wire. https://thewire.in/media/coronavirusindore-doctors-attacked Accessed 2 Aug 2020

Thian V (2020) Made in Malaysia: How mosque event spread virus to SE Asia. Al Jazeera, 18 March. https://www.aljazeera.com/news/2020/03/malaysia-mosqueevent-virus-hotspot-se-asia-200318021302367.html Accessed 2 Aug 2020

Trivedi S (2020) Coronavirus|The story of India’s largest COVID-19 cluster. The Hindu, 11 April. https://www.thehindu.com/news/national/coronavirusnizamuddin-tablighi-jamaat-markaz-the-story-of-indias-largest-COVID-19cluster/article31313698.ece Accessed 2 Aug 2020

Tsfati Y, Cohen J (2013) The Third-Person Effect, Trust in Media, and Hostile Media Perceptions. Perceptions of Media and Media Effects. In: Angharad N. Valdivia, Erica Scharrer (eds) The International Encyclopedia of Media Studies: Media Effects/Media Psychology. Blackwell Publishing Ltd, pp. 2-19

Ullah AKMA (2011) HIV/AIDS related stigma and discrimination: a study of healthcare providers in Bangladesh. J Int Assoc Providers AIDS Care 10 (2):97-104. https://doi.org/10.1177/1545109710381926

Wagner W, Holtz P, Kashima Y (2009) Construction and deconstruction of essence in representating social groups: identity projects, stereotyping and racism. J Theory Soc Behav 39:3
Wagner W, Kronberger N, Seifert F (2020) Collective symbolic coping with new technology: knowledge, images and public discourse. Br J Soc Psychol 41 (3):323-343. https://doi.org/10.1348/014466602760344241

Waxler NE (1992) Learning to be a Leper: a case study in the social construction of illness. In: Mishler E (ed) Social Contexts of Health, Illness and Patient Care. Cambridge University Press, Cambridge, pp. 169-192

Wester M, Giesecke J (2018) Ebola and healthcare worker stigma. Scand J Public Health. 47(2). https://doi.org/10.1177/1403494817753450

Williams M, Amoateng P (2012) Knowledge and Beliefs about cervical cancer screening among men in Kumasi, Ghana. Ghana Med J 46:147-151. https:// www.ncbi.nlm.nih.gov/pmc/articles/PMC3645156/

Yadav J (2020, 4 April) Indians are Fighting Against Coronavirus and BJP IT Cell is fighting Against Indians. The Print. https://theprint.in/opinion/pov/indiansare-fighting-against-coronavirus-and-bjp-it-cell-is-fighting-against-indians/ 395058/ Accessed 2 Aug 2020

Yamunan S (2020) Tablighi Jamaat: How did the government fail to detect a coronavirus infection hotspot? Scroll.in. https://scroll.in/article/957891/ tablighi-jamaat-how-did-the-government-fail-to-detect-a-coronavirusinfection-hotspot Accessed 2 Aug 2020

\section{Competing interests}

The authors declare no competing interests.

\section{Additional information}

Correspondence and requests for materials should be addressed to D.B.

Reprints and permission information is available at http://www.nature.com/reprints

Publisher's note Springer Nature remains neutral with regard to jurisdictional claims in published maps and institutional affiliations.

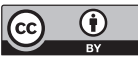

Open Access This article is licensed under a Creative Commons Attribution 4.0 International License, which permits use, sharing, adaptation, distribution and reproduction in any medium or format, as long as you give appropriate credit to the original author(s) and the source, provide a link to the Creative Commons license, and indicate if changes were made. The images or other third party material in this article are included in the article's Creative Commons license, unless indicated otherwise in a credit line to the material. If material is not included in the article's Creative Commons license and your intended use is not permitted by statutory regulation or exceeds the permitted use, you will need to obtain permission directly from the copyright holder. To view a copy of this license, visit http://creativecommons.org/ licenses/by/4.0/

(C) The Author(s) 2021 